\title{
Describing Local Development in Indigenous Peoples
}

\author{
Dante Ayaviri Nina ${ }^{1}$, Gabith Quispe Fernandez ${ }^{1} \&$ Patricio Sánchez Cuesta ${ }^{1}$ \\ ${ }^{1}$ Faculty of Political and Administrative Sciences, National University of Chimborazo, Ecuador \\ Correspondence: Dante Ayaviri, National University of Chimborazo, Ecuador. Tel. 593-9-6937-7165. E-mail: \\ dayaviri@unach.edu.ec
}

Received: October 9, 2018

Accepted: December 11, 2018

Online Published: January 31, 2019

doi:10.5539/jsd.v12n1p148

URL: https://doi.org/10.5539/jsd.v12n1p148

\begin{abstract}
Practices and modes of development planning have focused on researchers, because the development of communities and states depends on them, and it has its importance in all territories, as well as the practices and processes of construction of development. The article aims to identify the practices that rural communities have in relation to local development, specifically addresses the |Aymara communities of Bolivia. To do this, a survey of leaders of the region was carried out; on the other hand, development plans and specialized literature in the field of development have been reviewed. The results establish that local development approaches the theory of endogenous development, given the practices and the role played by actors in the development processes, which involved solid and inclusive participative community organizations, a leading role in the consolidation of productive, organizational and planning systems, based on values, ancestral and cultural customs of territory with a focus on sustainability.
\end{abstract}

Keywords: local development, Aymara communities, indigenous peoples

\section{Introduction}

People participation showed important advances in terms of the development and consolidation processes, as well as, in democracy and rights dependence, this participation of the population is fundamental for the consolidation of regional economic structures (Kempf, 2003; Aguilar, 2007). In the case of the indigenous communities, this practice and deepening participation favor the development of territories (Renshaw \& Wray, 2004), and these have allowed development and strengthening of productive and cultural systems, revaluing the ancestral knowledge that is a characteristic of the communities (Young, 1995, Hall \& Patrinos, 2005). Therefore, the strengthening of planning systems and development emerge as a peremptory task for consolidation of current development models in Latin America (Alonso and Ponce, 2015), and of all populations.

Authors such as Galarza (2015), points out that the characteristics of indigenous rural communities have differentiated ethno-cultural identities, which gradually established a legal framework in favor of the collective rights of the indigenous communities of Bolivia, which are incorporated into the Political Constitution, which provides a legal framework for the collective rights exercise of political, economic, cultural, legal, territorial and participatory dimensions (Constantinescu and Sporis, 2006; Molina \& Vadillo, 2007), on the other hand, grants powers to strengthen civil society and affect the processes of construction and planning the development of indigenous communities. In Bolivia, Law No. 482 of the Autonomous Municipal Governments of 2014 is observed and recognizes the Municipal Council as a deliberative body and the Municipal Executive as the highest authorities of a municipal territory, based on independence, separation, coordination and cooperation between these bodies, indicating that the Mayors and Councilors, must perform functions inexcusably in the territorial jurisdiction of the Municipality, in which the participation of the Originating Authorities of the Municipal Territory are considered as actors of the operation and planning of the development of the territory, which in turn, contemplates the participation of the population in the planning processes as a mechanism of expression and incorporation of the needs and demands of the communities.

As mentioned above, participation is a form of integration and exercise of deepening the processes of building the development of communities, and control of their institutions, ways of life and development. Under these postulates, indigenous communities have the right to intervene in all phases of the process of building the development plans of their district (Renshaw \& Wray, 2004; Anaya, 2005; Stavenhagen, 2008; Yrigoyen, 2008; Boamah, 2013; Felicetti, 2016). On the other hand, the consultation and dialogue in planning processes is 
determinant in the construction of the community welfare state, according to Bengoya (2000) and Stavenhagen (2008), they are rights through which the State is obliged to implement processes of dialogue with indigenous peoples before taking concrete measures that could affect them; therefore, it also guarantees and validates other collective rights (Anaya, 2005). According to O'donnell (1997), Bilbeny (2002), this is done before adopting measures in the development plans.

The fundamental aspect on which the present research work is constituted is the participation of the Originating Authorities (indigenous peoples or communities); concept that is approached from a normative and process approach. Normative, because it conceives participation as a mean that sustains democracy for citizens, with emphasis on the human rights of populations (UNDP, 2004), and ethno development, understood as the control of indigenous peoples of the processes and instruments linked to their development, and a development approach based on rights (Bilbeny, 2002; DANIDA, 2005; Oliva, 2005; Luca et al., 2007; Stavenhagen, 2008; Yrigoyen, 2008), Process, because analyzes political aspects as the result of the interaction between actors and the institutional framework, based on normative criteria and through analytical tools that configure and adopt mechanisms and forms of participation of the population (Stavenhagen, 2008; Yousuf \& Marinova, 2018).

The normative approach of the model affirms that indigenous peoples are the poorest, most unequal and excluded population sector (Bello \& Rangel, 2000; Oliva, 2005; PNUD, 2004; Psacharopoulos \& Patrinos, 1994; Stavenhagen, 2008; Valenzuela \& Rangel, 2004). Therefore, "being indigenous increases the chances of an individual being poor". (Hall \& Patrinos, 2005: 4) cited in (Martínez, 2015). The causal factors of such a situation can be multiple, however, as argued by researchers such as: Aparicio (2005), Bello (2004), Clavero (1994), Florescano (1997), Stavenhagen (2008), Yrigoyen (2008) in Martínez (2009) point out that a fundamental element of the inequality of indigenous peoples comes from a nineteenth-century model of State in Latin America, and that by not radically disrupting colonial structures, they marginalized politically, economically, socially, culturally and legally the indigenous peoples. Thus, cultural and ethnic diversity was associated, through the colonial system of the colony, with social, economic inequality. Indigenous peoples were considered unfit to govern themselves, so the State resorted to their protection as an instrument of expropriation of the capacity to control their destiny by themselves (Yrigoyen, 2008; Ibarra, 2000; Lechner, 2003). The component to be studied in this context is local development, since the practices are based on the interaction of the set of actors (Clark et al., 2010, Jouled et al., 2010 ) and that allow the coordination of productive activities and the conjunction of resources and mechanisms that give force to development (Mille, 2005; Silva et al., 2012).

Another important component of collective rights against indigenous guardianship is self-determination, which was classified as the "parent right" from which the rest of the rights emanate or are condensed (Anaya, 2005; Bello, 2004; Oliva, 2005; Botero, 2008; Yrigoyen, 2008), currently exercised by indigenous peoples or communities in Bolivia, is the case of the Jach'a Carangas nation There is an agreement that the political dimension of the collective rights of indigenous peoples are those that strengthened their community identity, this is framed in what they have termed as struggles and redefinitions of citizenship, processes that pose a greater inclusiveness based on the recognition and political, economic, social and cultural participation of the different actors (Hopenhayn, 2002; Bello, 2004; Bengoya, 2000; Leal, 2006; Crocker, 2007).

In relation to local development, it is understood that the process of local development is at the intersection of several intervention areas that are considered, in addition to economic policies and urban and local policies, which move to individuals (Constantinescu \& Sporis , 2006), that motivated by solving problems and needs, seek alternative solutions within populations and states (Haman, 2003; Guerin, 2006; Villalba et al., 2014; Cassalia \& Ventura, 2015), which grants autonomy in the development processes and search for social welfare (Yrigoyen, 2008; Jouled et al., 2010; Yunjeong, 2018). The concept of local development is defined as a particular form of regional development, one in which endogenous factors are central (Coffey \& Polese, 2005). In this line, Vázquez Barquero points out that "it is an optimistic interpretation of the development processes, which considers that the needs of the population would be well covered and the success of the local initiatives guaranteed when the population defines, assumes and controls projects no matter how limited the resources available to them and the investments made" (page 190). Under these antecedents, the local development is competence of the institutions of the State and in addition, of the local actors. Thus, the present study addresses particularities and characteristics of local development practices in the indigenous communities of Jach'a Carangas, located at the west of Oruro's Department, in Bolivia.

\section{Methodological Aspects}

First, a survey was conducted for sixty local municipal authorities of the studied population; likewise, the literature has been revised in relation to the subject, although it is a new topic in its configuration of the Bolivian State, there 
are advances and important material that was accessed. Indigenous communities include the system of worldview, belonging, identity, cultural practices of a people in their territory, defined territory as the physical space that houses life, where good economic, social, cultural and political living is developed (Parellada, 2006: 45), as is the case of the original region of the Nation (Note 1) Jach'a Carangas. According to Galarza (2015) there is a concern to know the degree of coordination between the Originating Authorities and the state institutions (City Halls) linked to the development, in particular to the construction of development plans, which would be limiting the synergistic impact of the actions in terms of local development results.

\section{Results}

The territory of Jach'a Carangas is located in the western part of the Bolivian Altiplano (Oruro), bounded on the north by the Department of La Paz; to the South with the Province Ladislao Cabrera; to the East with the Cercado Province, Saucarí, Poopó and Avaroa; and to the West with the Republic of Chile. Internally Jach'a Carangas is composed of eight provinces: Sajama, San Pedro de Totora, Nor Carangas, Carangas, Sur Carangas, Litoral, Sabaya and Mejillones; coming to comprise eighteen municipalities and more than 200 cantons (political division). Jach'a Carangas, responds to a social and economic organization based on a close and dependent relationship, whose indigenous identity is the Aymara, and based on principles such as territoriality, reciprocity, collectivity, complementarity, and others. Territorially, the region is organized by Thirteen Markas (Note 2) (similar to the cantons) of which six are in the partiality Aransaya and seven of the Urinsaya bias. The Markas in turn are composed by Ayllus (Guzmán, 2011), in its Aransaya Urinsaya parcialidades, the Carangas territory has more than a hundred Ayllus (Note 3). Its structure responds to the current territorial model.

It is important to reflect the number of Markas in the region of analysis, these are constituted in the political, territorial, economic and social unit intermediate between the Ayllu (minor unit) and Suyu (major unit). It is the result of the process of aggregation of a set of Ayllus and is also associated with the town or community where the houses of the Aymaras are located; and the Ayllus, which is the set of families linked by blood and related ties that make up a nucleus of economic production and distribution of consumer goods. These indigenous organizations are established in the rural communities of the Bolivian Altiplano, the composition is the following of the Markas: Totora, 9 Ayllus; Corque, 17 Ayllus; Choquecota, 8 ayllus; Curahuara, 14 ayllus; Santiago de Andamarca, 14 Ayllus; Huayllamarca, 8 Ayllus; Turkish, 10 Ayllus.

In order to know about the local planning system, we have consulted regarding the perception of the development planning processes in its territory, and its municipality. The answers obtained indicate that $43.3 \%$ affirm that the processes in their elaboration of the plans are bad and $26.7 \%$ indicate that they are very bad; while $23,3 \%$ say that the development process of the development plan is good, and $6.7 \%$ claim to be very good. Mainly they attribute that the processes are bad, due to the ignorance of the procedures and the involvement of the leaders and the population in these processes. In this line, regarding the support in the promotion and strengthening of the productive development that they receive from the Municipal Governments, they indicate in an important percentage that they are not prioritized or attended in a systematic way, and that they do not know the Strategic Programs of the region, these are covered according to the demands of the population, using various mechanisms of pressure for projects to be executed.

An important aspect that addressed the study is related to the forms elaborated development plans in the municipalities and the region. In the first place, it has been consulted if they know the processes of elaboration of the Municipal Development Plans and the Annual Operative Plans; In general, all those consulted affirm that they know both instruments; however, in a $60 \%$ of the population they do not know that they suffer adjustments and reformulations in the process for their approval. On the other hand, there have been consultations about the degree of participation of the community in the elaboration of the plans, in a percentage of $70 \%$ they indicate that the population participates in these processes, in their majority they consider that there are processes of consultation and not so of analysis of the regional and community problems. Specifically, the municipal authorities involve the population and its leaders in the processes of preparing and building the development plans; however, they do not intentionally and intentionally consider their participation by their leaders and the native indigenous population in the adjustment and reformulation processes that exist in the municipal development plans and annual plans.

In this line, one of the questions is related to the role played by the original authorities in the planning and execution processes of these plans. The answers make reference to that $30 \%$ of the leaders consider that activities are more directed to a social control, a mechanism that allows to guarantee the fulfillment of the development projects promoted by the municipality; $30 \%$ state that their participation refers to representation in events and activities of the Municipal Government, and $40 \%$ consider that the role they have as leaders is to participate in 
local development processes and the practices they develop are based on ancestral knowledge, customs, culture and their community organizations are the basis of the territorial development of people.

Currently Bolivia is implementing legislative reforms that allow a transformation in the administrative system and one of them is deepening and improvement of administrative decentralization through the implementation of the Departmental, Regional and Municipal Autonomies with the purpose that the actors and agendas of the local development, promote the development of the territories. To this end, four types of Autonomies are established: Departmental autonomy, regional autonomy, municipal autonomy and native indigenous peasant autonomy. In this regard, as it is a region that is composed of municipalities and that the region is considered ancestral culture corresponds two types of Autonomies, the municipal and native indigenous peasant.

In the field study, the consultation was made on which of the Autonomies consider and contemplate the ancestral knowledge and experiences for the planning of the territory, considering only two alternatives for the answer, a) Municipal Organic Letter and b) Peasant Native Indigenous Autonomy. They indicate in a percentage of $40 \%$ that are the Organic Letters (A Municipal Organic Charter is the expression of municipal autonomy understood as the exercise of self-government within the framework of what the Political Constitution of the State defines. The Municipal Organic Charter, comparatively, is a constitution or fundamental charter given by the citizens or neighbors of a municipality, since it implies a social pact that will be approved by the Deliberative Body or Municipal Council and approved by referendum), while $60 \%$ affirm that it is the Indigenous Peasant Native Autonomy that has competences in the application of knowledge and ancestral experiences in the planning and development processes, and of these they are incorporated into the plans in a timid manner and that there is a pending issue in the deepening and application of the same.

Likewise, it was consulted regarding the training received in relation to the Organic Charges and the Native Indigenous Peasant Autonomy) approximately $40 \%$ would have received such training in relation to the Municipal Organic Charters, and 30\% in relation to the Native Indigenous Autonomy Peasant Therefore, there is a weakness in their socialization and understanding of the importance and its processes involved in the planning of development.

Local development from the community system is collective and above all expresses the cultural, social and economic coexistence and identity of communities and families, while paradigms originate in a pre-rational stage of the collective psyche, but they are expressed on the basis of the nature of a cultural system and consequently will be the expression of life of the communities. The first of the genesis is charging specific contents according to the interpretation that each territory, each nation or each native indigenous people needs, within their plurality and their conceptions of life. As long as there are two visions within the same territory, on the one hand the system of the Ayllu and Markas, and on the other the municipalities and provinces, the original communities could be subjected systematically to the republican vision, because the norms that govern the state regime. It forces us to think in that logic, while the original authorities and the communities live in the Ayllus under their original form and worldview, the management of the municipalities (in some) does not adapt to the requirements of the indigenous communities.

On the other hand, the collective actions do not reflect an interaction between the actors, that is, the community organizations with the Municipal Governments and these also with the networks of local actors (associations, trade unions, non-governmental organizations), do not work coordinated; and we believe that they could collectively define the norms and rules that strengthen the institutional framework in terms of participation and coordination of the actors and thus guarantee relations of cooperation and trust, which ultimately make the local dynamics viable, explicit rules that rule and regulate cooperation between actors. Thus, one of the pillars on which development is based is the functioning of the institutions that are at the base of the synergic coordination of the collective action actors. In the community planning process, the Ayllus, Markas and communities are active subjects in the formulation of development plans assuming their commitment to its implementation.

On the other hand, one of the ways in which the development plan is built in the Jach'a Carangas region that flows into local development, is from the "bottom up" so that it is considered reciprocal, equitable, just and equal; its policies, programs and projects are framed in the aspirations, interests and community awareness, based on fundamental aspects that generate balance in the integral, concerted and equitable planning of the territory. The construction of local development is based on community organization, on cultural values and ancestral knowledge applying custom, population customs and also based on the knowledge acquired by the elderly, they assume the responsibility of holding positions of high hierarchy in each territory.

Thus, in conceptual terms, the territory is the administration of a space inhabited and interacting with resources and people in which they plan their development and processes without losing connection with the State and other 
actors (Alburquerque, 2004; Vázquez Barquero, 2004). In the vision of the development of the Jach'a Carangas territory, two development visions are identified: one referring to the recovery of an Andean cosmovision, its culture, traditions and ancestral knowledge, and another much more pragmatic in terms of its orientation towards new trends of development and that have to do with changes in the Western world; but in general it is framed in the endogenous development model, based on the search for solutions from the communities (Haman, 2003; Guerin, 2006; Cassalia and Ventura, 2015); in that line, Vázquez Barquero, (2002, 2007), Quispe and Ayaviri (2012) define it as which is produced from the territories in that the actors and agents of development act, and as a consequence mechanisms and levels of progress and innovation in the territories are established. Thus, the endogenous development policy emphasizes precisely that the development of a territory occurs when the institutional capacity is created and developed, capable of spreading innovation and knowledge through the productive system that stimulate the improvement of competitiveness and its local development (Ndabeni, 2016).

The development processes, therefore in the indigenous communities under study, implies the application of a series of norms and practices that regulate and organize the access and use of natural resources (land, water, vegetation, fauna, minerals) available, to ensure the sustainability of the life systems of the people in their territory (Shaffer et al., 2006; Jouled et al., 2010), considering, in turn, cultural aspects and values of local culture and customs (Guiso et al. al., 2006; Cassalia \& Ventura, 2015), to finally contemplate and benefit from public policies of the State. Therefore, the main actors of local development in Jach'a Carangas, is the local population, therefore the family and the community are the main actors that generate spaces for planning and implementation of the strategies, mechanisms of their productive, social systems, cultural and economic of the Ayllu and the Marka being that these have the knowledge and the experience regarding the management of their territory.

On the other hand, the local development in the Markas de Jach'a Carangas responds to the principles of sectorial and local planning, the Municipal Development Plan of the Municipalities are annexed to the Departmental Development Plan and the National Development Plan, therefore it is also a system constructed from "Up and down", understood from the theoretical point of view as the model of Policy Analysis (Friedmann, 1992; Jordana, 2007, Cazorla \& De los Rios, 2012), according to Friedmann (1992) politicians are the most responsible for planning and the State must support the political decision adopted, society and the economy have little relevance; and also approaches the model of Social Reform (Jordana, 2007), in which there is little community participation, and to a lesser extent, considers the ancestral knowledge in the construction of development, generating distrust in the communities that negatively affect the fulfillment of objectives, in this model according to Friedmann (1992) the State executes the planning with expert advice and minimal participation of the population. Thus, local development promoted and practiced in indigenous communities, have community bases that has remained over time, on the other hand, also takes into account (although without knowing it) theoretical approaches to development.

\section{Conclusions}

From the territorial decentralization a regional social power is formed according to the occupation and cultural use of the territory in agreement with the municipal autonomies concentrated in the diverse regions, like the region of Jach'a Carangas. The territorial reconfiguration allows generating more adequate planning and development units. The creation of spaces for dialogue and coordination of public policies in accordance with the regional customs and practices of the local peoples and social organizations, allows constituting the territorialized social power. From the opening of these processes, indigenous peoples, social, civic and community movements have a greater presence in the decision-making to the local development and in political management.

According to the study it has been identified that the Originating Authorities do not have sufficient knowledge or participation in the processes of adjustment and reformulation of municipality development plans. Although they know in a greater percentage about the importance of participation and of the norms and laws that mark their responsibility, they are not practiced or applied in a systematic way, other leaders even have little participation in the elaboration processes of development and operational plans, which constitutes its basis for local development practices.

Under the results achieved, the original communities of Jach'a Carangas, are in processes of search for their own development based on the resources, processes, visions, actors and agents of development, as they become involved, they could reach scenarios that allow them to improve the quality of life of their population. However, it is convenient to ask some questions in order to outline future research in this line: what type of participatory methodologies apply in the budget planning and construction of the plans, development projects of the region? What achievements did you obtain from the processes of community participation in the construction of territorial 
development? How do the contexts of changes that occur in the international order, such as globalization and technological progress, impact in the local development processes of the communities?

\section{References}

Aguilar Villanueva, L. F. (2007). La implementación de las políticas públicas. México.

Alburquerque, F. (2004). El Enfoque del Desarrollo Económico Local. CEPAL, Santiago.

Alonso, A., \& Ponce, J. (2015). El neoextractivismo como modelo de crecimiento en América Latina. Economía y Desarrollo, 154, 35-52

Anaya, J. (2005). Los pueblos indigenas en el derecho internacional. Ediciones Trotta, Madrid.

Bello, A. (2004). Etnicidad y ciudadanía en América Latina. La acción colectiva de los pueblos indígenas. Santiago: Comisión Económica para América Latina y el Caribe (CEPAL). Sociedad Alemana de Cooperación Técnica (GTZ).

Bello, Á., \& Rangel, M. (2000). Etnicidad, raza y equidad en América Latina y el Caribe. Comisión Económica para América Latina y el Caribe (CEPAL), Santiago.

Bengoa, J. (2000). La emergencia indígena en América Latina. Santiago: Fondo de Cultura Económica.

Bilbeny, N. (2002). Por una causa común. Ética para la diversidad. Edición Gedisa. Barcelona.

Boamah, N. A. (2013). Land Use Planning And Housing Situation In The Wa And Offinso South Municipalities, Ghana. Ethiopian Journal of Environmental Studies and Management, 4(6). https://doi.org/10.4314/ejesm.v6i4.13

Cassalia, G., \& Ventura, C. (2015). Toward an Integrated Cultural Plan for the City of Reggio Calabria: Culture as a Basis for Territorial Local Development. Laborest, 1, 45-56.

Cazorla, A., \& De los Ríos, I. (2012). Rural Development as Working whit People: a proposal for policy management in public domain. Ed. Adolfo Cazorla, Madrid.

Clark, G., Huxley, J., \& Mountford, D. (2010). Organising Local Economic Development: The Role of Development Agencies and Companies. OECD.

Coffey, W. J., \& Polese, M. (2005). The concept of local development: a stages model of endogenous regional growth. Canada: Springer Verlag.

Constantinescu, D., \& Sporis M. (2006). Economie regională - Economie locală, Piteúti: Independen $\dot{G} a$ Economică. Publishing House, USA.

Crocker, D. (2007). Deliberative Participation in Local Development, Journal of Human Development. Journal of Human Development, 8(3), 431-455.

DANIDA. (2005). Kit de herramientas. Mejores prácticas para incluir a los pueblos indígenas en el apoyo programático sectorial. Copenhague: Ministerio de Relaciones Exteriores de Dinamarca. Retrieved from http://www.netpublikationer.dk/um/5956/pdf/536220_web.pdf

Felicetti, M. (2016). Cultural Innovation and Local development: Matera as a Cultural District. Procedia - Social and Behavioral Sciences, 223, 614-618. https://doi.org/10.1016/j.sbspro.2016.05.366

Friedmann, J. (1992). Planificación para el siglo XXI: el desafío del posmodernismo. Revista EURE - Revista De Estudios Urbano Regionales, 18, 55-78.

Galarza, F. (2015). Visiones y Problemas en la Nación Jachà Karangas. Tesis de Maestría en Desarrollo Económico Local, Universidad Técnica de Oruro, Bolivia.

Guerin, T. F. (2006). A survey of sustainable development initiatives in the Australian mining and minerals industry. Minerals \& Energy - Raw Materials Report, 20(3), 11-44, https://doi.org/10.1080/14041040500537129

Guiso, L., Sapienza, P., \& Zingales, L. (2006). Does Culture Affect Economic Outcome. Journal of Economic Perspectives, 20(2), 23-48.

Guzmán, O. Q. (2011). Apuntes acerca del sistema de cargos en los Ayllus Bolivianos. Revistas Bolivianas, Temas Sociales, 31, 201-240.

Hamann, R. (2003). Mining companies role in sustainable development: The 'Why' and 'How' of corporate social responsibility from a business perspective. Development Southern Africa, 20(2), 37-54. 
https://doi.org/10.1080/03768350302957

Hopenhayn, M. (2002). Ciudadanía descentrada en tiempos de globalización. En Marco Antonio Calderón, Willem Assies y Ton Salman (comp.). Ciudadanía, cultura política y reforma del Estado en América Latina. Zamora: El Colegio de Michoacán, Instituto Federal Electoral estatal.

Ibarra, P. (2000). ¿Qué son los movimientos sociales? Una mirada sobre la red. Anuario de movimientos sociales, Icaria, 4, 9-26.

Jordana, J. (2007). La Gestión de la I+D+i Agroalimentaria: Un modelo basado en el Aprendizaje Social. Tesis Doctoral, Universidad Politécnica de Madrid. España.

Jouled, M., Kolosy, K., \& Pellegrin, J.-P. (2010). Cohesion Policy Support For Local Development: Best Practice and Future Policy Options. European Commision, Institut Jacques Delors.

Kempf, I. (2003). Pobreza y pueblos indígenas: más allá de las necesidades. CIP-FUHEM, Madrid.

Leal, N. (2006). Ciudadanía activa: La construcción del nuevo sujeto indígena. Revista Opción, 22(49), 9-24. Retrieved from http://www.redalyc.org/articulo.oa?id=31004902

Lechner, N. (2003). Estado y sociedad en una perspectiva democrática. En Polis. Revista de la Universidad Bolivariana, 2(6), 36-57.

Luca, L. M., \& Gima, K. A. (2007). Market Knowledge Dimensions and Cross-Functional Collaboration: Examining Different Routes to Product Innovation Performance. Journal of Marketing, 71, 96-112. Retrieved from https://www.jstor.org/stable/30162132

Martínez Espinoza, M. I. (2009). La participación de los pueblos indígenas en los proyectos de cooperación al desarrollo de la Comisión Europea. Los casos de México y Guatemala, Tesis Doctoral, Universidad de Salamanca.

Martínez Espinoza, M. I. (2015). Reconocimiento sin implementación Un balance sobre los derechos de los pueblos indígenas en América Latina. Revista Mexicana de Ciencias Políticas y Sociales, 60, 251-277. Retrieved from http://www.scielo.org.mx/scielo.php?script=sci_arttext\&pid=S0185-19182015000200251

Mille, M. (2005). The University, Knowledge Spillovers and Local Development: The Experience of a New University. Higher Education Management and Policy, 16, 3-15. https://doi.org/10.1787/hemp-v16-art24-en

Molina, R., \& Vadillo, A. (2007). Los Derechos de los Pueblos Indígenas en Bolivia. Una introducción a las normas, contextos y procesos. Centro Boliviano de Estudios Multidisciplinarios, La Paz, Bolivia.

Ndabeni, L., Rogerson, C., \& Booyens, I. (2016). Innovation and Local Economic Development Policy in the global South: New South African perspectives, Local Economy: The Journal of the Local Economy Policy Unit, 31(1), 299-311. https://doi.org/10.1177/0269094215621865

O'donnell, G. (1997). Contrapuntos. Ensayos escogidos sobre autoritarismo y democratización. Buenos Aires: Paidós.

Oliva Martínez, D. (2005). La cooperación internacional con los pueblos indígenas. Desarrollo y derechos humanos. Madrid: Centro de Comunicación, Investigación y Documentación entre Europa, España y América Latina (CIDEAL). España.

Ospina, J., \& Salmón, E. (2011). Participación Política Indígena y Políticas Públicas para Pueblos Indígenas en América Latina. Konrad Adenauer Stiftung. Bolivia.

Parellada, P. (2006). Pueblos indígenas en aislamiento voluntario y contacto inicial en la amazonia y el Gran Chaco. Ediciones TAREA, Lima Perú.

PNUD, Programa de las Naciones Unidas para el Desarrollo. (2004). Participación popular. Informe sobre Desarrollo Humano 1993. Madrid: Centro de Comunicación, Investigación y Documentación entre Europa, España y América Latina (CIDEAL).

Quispe Fernández, G. M., \& Ayaviri, D. (2012). Los actores en el desarrollo económico local. Un estudio en América Latina. Perspectivas, 30, 71-116.

Renshaw, J., \& Wray, N. (2004). Indicadores de bienestar y pobreza indígena. Banco Interamericano de Desarrollo. Washington.

Sánchez Botero, E. (2008). Consulta, participación y consentimiento en el marco de la declaración de las Naciones Unidas. Lima. 
Shaffer, R., Deller, S., \& Marcouiller, D. (2006). Rethinking Community Economic Development. Economic Development Quaterly, 20, 59-74. https://doi.org/10.1177/0891242405283106

Silva, Y. F. et al. (2012). University and The Local Development in Goias-Brazil. Procedia-Social and Behavioral Science, 269-278.

Stavenhagen, R. (1997). Las organizaciones indigenas: actores emergentes en América Latina. En Manuel Gutiérrez Estévez, Ediciones Identidades Étnicas. Madrid.

Valenzuela, M. E., \& Rangel, M. (2004). Desigualdades entrecruzadas: pobreza, género, etnia y raza en América Latina. OIT, Santiago.

Vázquez Barquero, A. (2002). Endogenous development. Londres y Nueva York, Routledge.

Vázquez Barquero, A. (2007). Desarrollo endógeno. Teorías y políticas de desarrollo territorial. Investigaciones Regionales, 11, 183-210.

Villalba, U., Jubeto, Y., \& Guridi, L. (2014). Participation and gender in Latin America: perspectives from decentralized cooperation and Local Human Development approaches, Community Development Journal, 49(2), 228-244. https://doi.org/10.1093/cdj/bst032

Young, I. (1995). Polity and group difference: a critique of the ideal of universal citizenship. En Beiner, Ronald. Theorizing citizenship, 6, 175-207. Retrieved from https://www.jstor.org/stable/2381434

Yousuf, A., \& Marinova, D. (2018). Understanding Sense of community in Subiaco, Western Australia A Study of Human Behaviour and Movement Patterns. Journal of Sustainable Development, 11(5), 1-17. https://doi.org/10.5539/jsd.v11n5p1

Yrigoyen Fajardo, R. (2008). De la tutela a los derechos de libre determinación del desarrollo, participación, consulta y consentimiento. Fundamentos, balance y retos para su implementación. Evento sobre consulta previa. Agencia Nacional de Hidrocarburos-Instituto Colombiano de Antropología e Historia. Bogotá.

Yunjeong, Y. (2018). Community participation for sustainable rural development: revisiting South Korean rural modernization of the 1970s. Community Development Journal, 53(1), 61-77, https://doi.org/10.1093/cdj/bsw023

\section{Notes}

Note 1. Article 30-I of the Political Constitution of the State defines a Nation and an indigenous people as the whole human community that shares cultural identity, language, historical tradition, institutions, territoriality and worldview.

Note 2. Marka.- It is the administrative center of every community and the place of secondary residence of the original families; It is also the ceremonial center, Marka can be defined as a common space of the territorial ayllu. See. The theory of vertical eco-symbiotic complementarity. Hisbol. 1987.

Note 3. Ayllu.- community system of land tenure, which is formed by a set of people descended from a common root grouped around a Kuraka or Boss.

\section{Copyrights}

Copyright for this article is retained by the author(s), with first publication rights granted to the journal.

This is an open-access article distributed under the terms and conditions of the Creative Commons Attribution license (http://creativecommons.org/licenses/by/4.0/). 